\title{
Why do People Disseminate Fictitious Accounts? A Systematic Analysis of snopes.com
}

\author{
Simon A Moss ${ }^{1} \&$ Samuel G. Wilson ${ }^{2}$ \\ ${ }^{1}$ School of Psychology, Counselling, and Psychotherapy, Cairnmillar Institute, Australia \\ ${ }^{2}$ Swinburne Leadership Institute, Swinburne University of Technology, Australia \\ Correspondence: Dr Simon Moss, Cairnmillar Institute, 993 Burke Road, Camberwell, 3124, Australia. E-mail: \\ Simon.Moss@cairnmillar.edu.au
}

Received: June 27, $2013 \quad$ Accepted: August 12, $2013 \quad$ Online Published: November 5, 2013

doi:10.5539/ijps.v5n4p1 URL: http://dx.doi.org/10.5539/ijps.v5n4p1

\begin{abstract}
People often disseminate fictitious information and contrived anecdotes, some of which can be destructive. This paper explores the proposition that most, if not all, fictitious information can be classified into four clusters. Each cluster reinforces one of four underlying determinants of positive emotions - unambiguous duties, moral authorities, extensive capabilities, and stable values over time. This framework is derived from socio-emotional selectivity theory, self-discrepancy theory, and the meaning maintenance model. To assess these propositions, 1500 fictitious claims, derived from snopes.com, were subjected to thematic analysis. To code these claims, all nouns and verbs were translated to broader categories. Then, researchers sorted these abstracted claims into 88 piles of overlapping accounts. These 88 accounts were next sorted into 19 broader piles, each reflecting a distinct theme. All 19 themes aligned to one of the four underling determinants of positive emotions. These findings indicate that, arguably, the need to curb negative emotions and to foster positive emotions motivates these biased and fictitious accounts. The findings also highlight several distinct avenues in which each of these four needs can be fulfilled. The implications of these findings to a range of issues, from violence and mental illness to advertising and marketing, are discussed.
\end{abstract}

Keywords: cognitive biases, emotions, fictitious claims, meaning, need for closure

\section{Introduction}

Although ubiquitous throughout the ages, social media has underscored the prevalence of misguided and fictitious information. Some people, for example, maintain that swine flu was a campaign, contrived by rivals of the pork industry or by pharmaceutical companies (King, 2010). Other people assert that Michael Jackson faked his death merely to circumvent his debts (King, 2010). Some individuals even maintain that Barack Obama is actually a radical Muslim or that producers decide who will win American Idol (Roeper, 2008). Often, these fictitious claims or contrived accounts are innocuous. Yet, in some circumstances, these distortions can provoke violent and destructive behavior. Violent extremism, for example, is often ascribed to misguided beliefs about modern society. The decrees and declarations of Sayyid Qutb (1964), such as his belief that "Mankind today is on the brink of a precipice" (cited in Saucier, Akers, Shen-Miller, Knezevic, \& Stankov, 2009), were central to the formation of Al Qaeda. Alternatively, fictitious allegations can translate into injustices and other complications.

Scholars and practitioners, therefore, need to uncover, and then to prevent, the origins of these fictitious claims. This paper invokes socio-emotional selectivity theory (Carstensen, 1995), self-discrepancy theory (Higgins, 1987), and the meaning maintenance model (Heine, Proulx, \& Vohs, 2006) to develop a theory that characterizes the source of these beliefs. A systematic analysis of past distortions is then undertaken to corroborate this theory.

\section{The Motivation to Regulate Emotions Rather than to Accrue Knowledge}

Central to socio-emotional selectivity theory is the distinction between two fundamental motivations: the motivation of individuals to accrue knowledge and resources and the motivation of individuals to regulate emotions (Carstensen, 1995, 2006). People sometimes feel their identity, including their goals, values, and interests, are unlimited in time (Carstensen, Isaacowitz, \& Charles, 1999). Many young people, for example, feel 
their identity will last indefinitely (Carstensen, 1995). Consequently, they are especially motivated to accumulate resources that could be beneficial to their future, such as knowledge and insight (Carstensen, 2006). They value accurate and constructive information, vigorously and doggedly (DeWall, Visser, \& Levitan, 2006). They do not accept opinions they feel are erroneous merely to appease someone else and, therefore, may sometimes appear quarrelsome (DeWall et al., 2006).

In contrast, individuals may instead feel their identity is limited in time, and this perception is common in people who are elderly or afflicted with a terminal disease (Carstensen \& Fredrickson, 1998). Therefore, rather than accrue beneficial knowledge and accurate information, their primary motivation is to improve their emotions (Pruzan \& Isaacowitz, 2006). In this state, memory, attention, and sensemaking is biased towards positive features (Charles, Mather, \& Carstensen, 2003; Mather \& Carstensen, 2003, 2005).

Socio-emotional selectivity theory, therefore, implies that many distorted assumptions can be ascribed to the motivation of individuals to alleviate negative emotions and to foster positive emotions. In particular, this motivation may bias the memory, attention, and interpretations of individuals and diminish the pursuit of accurate information.

\section{The Cognitive Underpinnings of Specific Emotions: Self-Discrepancy Theory}

As socio-emotional selectivity indicates, memory, attention, and sensemaking may be biased to improve emotions. Therefore, to understand the source of fictitious information, researchers need to characterize the cognitive biases that enhance these affective states.

Many researchers have formulated theories and frameworks that explain this association between cognition and affect. Personality systems interaction theory (e.g., Kazen, Kaschel, \& Kuhl, 2008; Kuhl, 2000), cognitive appraisal theory (Folkman, Lazarus, Gruen, \& DeLongis, 1986), control theory (Carver \& Scheier, 1990), and self-discrepancy theory (Higgins, 1987) epitomize these frameworks.

Although all these frameworks are illuminating, self-discrepancy theory may be especially pertinent to this discussion. In particular, self-discrepancy theory characterizes the family and social dynamics from which specific emotions evolve (Higgins, 1987). Consequently, when this theory is invoked, practitioners may be able to advocate social changes that diminish the need in individuals to regulate emotions and to disseminate or embrace fictitious claims.

According to self-discrepancy theory, during their childhood, individuals learn which behaviors they should enact to prevent immediate punishment and which behaviors they should enact to attract future rewards (Higgins, 1987, 1989). As they mature, these individuals glean an array of principles from these experiences, such as "To prevent punishment, do not emit loud noises" or "To attract rewards, evoke laughter in other people". The principles that are distilled to prevent punishment are conceptualized as social duties or obligations, whereas the principles that are distilled to attract rewards are conceptualized as future hopes and aspirations (Higgins, 1997).

\subsection{Impending Punishment}

Sometimes, individuals are not sure which of their duties they should attempt to satisfy. To illustrate, while they drive a car, they may not be certain which authorities, such as a rebellious passenger, the police, or the parents, will evaluate their behavior and potentially deliver punishments. In addition, the demands of each authority, such as a parent, may shift unexpectedly over time. Individuals may not, therefore, be sure of which duties or obligations this authority expects them to fulfill now. As a consequence, they feel they may not satisfy these duties and, therefore, may be punished (Higgins, 1987, 1989), coinciding with feelings of apprehension, agitation, and anxiety (Higgins, 1987, 1989, 1999). Indeed, as many studies have shown, whenever people feel they have not fulfilled their duties, as measured by the Selves Questionnaire or other instruments, they are more likely to report these unpleasant feelings (Boldero \& Francis, 1999; Boldero, Moretti, Bell, \& Francis, 2005; Higgins, 1987, 1999; Scott \& Hara, 1993; Strauman, 1989).

Yet, even if individuals feel they have fulfilled their social duties, they may still feel they could be punished. That is, they may assume the authorities that can dispense punishment, such as parents, police, principals, leaders, or even dominant peers, can be unjust and unpredictable. For example, at work, a manager who commits an error may blame employees rather than assume responsibility. The employees, therefore, may fulfill all their duties but still be punished unfairly (Deutsch, 1975). Therefore, as a consequence of either ambiguous duties or unjust authorities, individuals may anticipate punishment and thus experience apprehension, agitation, and anxiety (Higgins, 1987). In contrast, if duties are unambiguous and authorities are just, the prospect of punishment dissipates, and feelings of contentment are experienced instead (Higgins, 1987). 


\subsection{Withdrawal of Rewards}

The origins of dejection diverge from the origins of anxiety. In particular, in some circumstances, individuals do not feel they have developed the capabilities to fulfill their aspirations (Higgins, 1999). They may not feel their skills, abilities, knowledge, wealth, social networks, or personal qualities are adequate. Consequently, they do not believe they will receive the rewards they had anticipated, such as praise from their peers. The ensuing sense of loss manifests as dejection, sadness, and resignation (Higgins, 1987, 1989). Indeed, as many studies demonstrate, when people doubt their capacity to achieve their aspirations, they are more likely to experience these negative emotions (Boldero \& Francis, 1999; Boldero et al., 2005; Scott \& Hara, 1993; Strauman, 1989).

However, even if individuals feel they can achieve their aspirations, they are not always sure these accomplishments will be rewarded in the future. They may feel the values of their community, and hence which achievements are rewarded, may vary arbitrarily over time, sometimes called a decrease in instrumentality rather than expectancy (Vroom, 1982). For example, a company may reward employees who embrace risks one month but reward employees who behave cautiously the next month. Again, as the prospect of reward diminishes, the likelihood of dejection increases (Higgins, 1987).

In short, unless their duties are unambiguous, their authorities are moral, their capabilities are extensive, and the values of their community are consistent over time, individuals are likely to experience negative emotions - especially anxiety or dejection. These four conditions, derived from the previous discussion on self-discrepancy theory, are outlined in the first column of Table 1.

Table 1. Conditions and biases that enhance emotions or foster meaning

\begin{tabular}{|c|c|c|}
\hline $\begin{array}{l}\text { Conditions that prevent negative } \\
\text { emotions }\end{array}$ & $\begin{array}{l}\text { Biases that instill the belief that } \\
\text { each condition is fulfilled }\end{array}$ & $\begin{array}{l}\text { Biases that are provoked by threats } \\
\text { to meaning }\end{array}$ \\
\hline Unambiguous duties & $\begin{array}{l}\text { Need for closure: that is, clarity } \\
\text { over who is a legitimate authority } \\
\text { and the expectations of this } \\
\text { authority }\end{array}$ & Need for closure \\
\hline Moral authorities & $\begin{array}{l}\text { Overestimation of justice and } \\
\text { morality }\end{array}$ & Overestimation of morality \\
\hline Extensive capabilities & Self-enhancement biases & Inflated self-esteem \\
\hline Consistent values over time & $\begin{array}{l}\text { Overestimation of stability in } \\
\text { values }\end{array}$ & Symbolic immortality \\
\hline
\end{tabular}

\section{Biases that Foster Positive Rather than Negative Emotions}

If motivated to regulate their emotions rather than to amass accurate information, individuals may bias their memory, attention, and interpretations to information that conforms to these conditions. For example, if individuals respect one authority, but dismiss other authorities, they are more certain of which duties to observe. Likewise, when people gravitate to settings in which the expectations and standards of authorities are predictable and unequivocal, they are more certain of which duties to satisfy.

This veneration of one authority and inclination towards predictable, unequivocal settings aligns to the concept of need for closure (Webster \& Kruglanski, 1994), defined as the need in some individuals to reach conclusions prematurely and to accept these conclusions uncritically (Kruglanski \& Webster, 1996). Specifically, when people experience a need for closure, they embrace, and do not question, one authority or ideology (Kruglanski, Shah, Pierro, \& Mannetti, 2002; Van Hiel, Pandelaere, \& Duriez, 2004), and tend to gravitate to predictable, coherent settings. This need for closure, therefore, should diminish the likelihood that duties seem ambiguous and alleviate apprehension, agitation, and anxiety, at least until these individuals are exposed to information that shatters these biased assumptions.

Biases may also increase the likelihood that authorities seem just and fair. Indeed, many studies have corroborated the just world bias (e.g., Correia, Kamble, \& Dalbert, 2009; Janoff-Bulman, Timko, \& Carli, 1985), which is the inclination to assume the world is just and that people receive the rewards and punishments they deserve (Lerner, 1980; see also Dalbert, 2001). When people entertain these biases, the prospect of punishment should decrease, and feelings of anxiety should abate (Higgins, 1987). 
In addition, many biases increase the probability that people feel they can achieve their aspirations. For example, individuals are not as able to recall unfavorable, compared to favorable, information about themselves (Croyle, Loftus, Barger, Sun, Hart, \& Gettig, 2006). They also overestimate the importance of traits that represent their strengths (Lewicki, 1983). These tendencies, and many similar distortions, are collectively called self-enhancement biases (Bosson, Brown, Zeigler-Hill, \& Swann, 2003) and have been shown to evoke positive emotions (Taylor \& Brown, 1988), at least transiently.

Finally, some biases may increase the likelihood that values seem stable over time, analogous to a coherent worldview (Arndt, Greenberg, \& Cook, 2002). For instance, people tend to perceive anyone who challenges their beliefs about the world as misguided or hostile (e.g., Arndt et al., 2002). The second column of Table 1 summarizes these four sets of biases, each of which should alleviate negative emotions.

\section{Alignment to the Meaning Maintenance Model}

These four constellations of biases closely align to another taxonomy, embedded with the meaning maintenance model (Proulx \& Heine, 2006, 2008, 2009). Specifically, according to this model, when people feel their sense of meaning is threatened and their life seems futile or incoherent, they tend to exhibit one of four biases, specified in the third column of Table 1 (Heine et al., 2006). In particular, they exhibit a need for closure (Van Tongreen \& Green, 2010), they overestimate the extent to which society is moral and just (Randles, Proulx , \& Heine, 2010), they inflate their self-esteem (Van Tongreen \& Green, 2010), and they overrate the degree to which their achievements and contributions will be valued in the future, called symbolic immortality (Van Tongreen \& Green, 2010).

This alignment between self-discrepancy theory and the meaning maintenance model is not surprising. In particular, from the perspective of self-discrepancy theory, when individuals entertain these biases, their anxiety and dejection subside (Higgins, 1987). This decrease in anxiety enables individuals to shift their attention to future aspirations rather than immediate concerns (cf., Derryberry \& Reed, 1998). This decrease in dejection enables individuals to feel they can achieve these aspirations (Higgins, 1987). Their activities now seem pertinent to these aspirations of the future, imbuing their life with a sense of meaning. Consequently, when people feel their life is futile, these four biases should restore this sense of meaning.

\section{Overview of this Study}

To reiterate, four constellations of biases seem to alleviate negative emotions and foster positive emotions. Consequently, if motivated to enhance their emotions, people should be motivated to concoct, disseminate, and embrace information that reinforces these biases. If this premise is correct, fictitious claims and contrived anecdotes should align to the four constellations of biases that curb negative emotions, as outlined in Table 1. To assess this possibility, this study examines whether popular misconceptions and fabrications do indeed correspond to these four constellations.

To conduct this study, fictitious claims were derived from snopes.com, a website that presents evidence to confirm or refute thousands of folklores. For example, one entry provides evidence that substantiates the prevailing belief that $S$ really was the middle name of Harry Truman. Another entry presents evidence that refutes the popular belief that Benito Mussolini increased the punctuality of trains in Italy. In this study, an extensive ample of fictitious claims was subjected to a thematic analysis to unearth constellations of biased assumptions.

\section{Method}

\subsection{Identification of Fictitious Claims}

The snopes.com website classifies all claims into false, true, ambiguous, or uncertain. For this study, only the fictitious claims were subjected to the analysis. In particular, in this study, saturation was reached after a sample of 1500 claims was examined. That is, when the researchers examined another 100 claims, no additional codes or themes were uncovered (see Bowen, 2008, for a discussion about saturation).

To optimize this sample of fictitious claims, two key phases were conducted. First, one researcher identified duplicates, defined as fictitious claims that had been assigned to more than one category and, therefore, appeared more than once on the website. For example, the contention that "KFC restaurants stopped using the word chicken to describe their products because they are serving meat from genetically modified animals" had been allocated to the category "Horrors" under the subcategory "Contaminated food" but also had been allocated to the category "Food" under the subcategory "Warnings". Second, another researcher attempted to identify fictitious claims that actually comprise two or more divisible folklores. To fulfill this objective, the researcher examined all fictitious claims that entailed the word "and". 
Most of these fictitious claims could not be divided into two or more claims. For example, in most instances, the word "and" separated two or more related items in a list-such as "A mixture of Mentos and Coca-Cola killed two Brazilian children". In other instances, the phrase after the word "and" merely exemplified, clarified, or verified the phrase before this word, such as "President Bush misspoke at a right-to-life rally and repeatedly said "feces' instead of 'fetus"'.

However, in some instances, the two phrases before and after the word "and" were independent. The second phrase did not confirm or clarify the first phrase. An example is "Muslim girls buried alive by their father are fed and comforted by Jesus until rescuers came for them". Independent claims, provided they had both been invalidated, were divided into two distinct folklores. In this example, the two folklores were "Muslim girls were buried alive by their father" are "Trapped Muslim girls were fed and comforted by Jesus until rescuers came for them".

\subsection{Classification of Fictitious Claims}

Consistent with the procedures that were recommended by Braun and Clarke (2006) to conduct thematic analysis, the two psychology researchers first perused 1000 of these fictitious claims to form initial impressions. Second, they attempted to assign initial codes to these data.

In particular, to code each of these 1000 fictitious claims, the researchers converted specific nouns and verbs to broader categories. For example, to code the folklore "The Marlboro brand of cigarettes is owned by the $\mathrm{Ku}$ Klux Klan", "The Marlboro brand" was translated to "A large corporation", "owned by" was translated to "associated with" and "the Ku Klux Klan" was translated to "a malevolent entity". This claim was thus reduced to "A large corporation is associated with a malevolent entity". This phase was undertaken to merge fictitious claims that are equivalent, at least after unnecessary details are eliminated. The two researchers coded all the claims in isolation from each other.

Then, codes that overlapped considerably with one another were amalgamated. To fulfill this goal, each code was written on a separate card. Four psychologists, including the two researchers, distributed the cards into piles of overlapping codes. If all four researchers distributed two cards into the same pile, the corresponding codes were then amalgamated. That is, two codes that were always sorted into the same pile were subsequently classified as one broader code.

Next, as suggested by Braun and Clarke (2006), to validate these amalgamated codes, two researchers assessed the degree to which this scheme is consistent with another 100 fictitious claims. That is, the two researchers, in isolation from each other, assigned this set of folklores to the existing piles of codes. They repeated this process with other sets of 100 claims until all the folklores in this set could be assigned to the existing piles, indicating that saturation had been reached (Bowen, 2008).

After this phase, and compatible with the recommendations that were stipulated by Braun and Clarke (2006) to uncover broader themes, the four psychologists then attempted to reduce these amalgamated codes into larger clusters. Specifically, a definition of each amalgamated code was printed on a separate card. Each researcher, in isolation from each other, sorted these cards into piles that seemed to overlap with each other. Finally, each researcher classified these themes into one of the four constellations of biases, as defined in Table 1.

\section{Results}

\subsection{Preliminary Coding of Data}

Not all the fictitious claims could be coded unambiguously. That is, for some of these claims, the researchers were not certain to which broader category a particular noun or verb should be assigned. To illustrate, one folklore, since refuted, is that "Mel Gibson was the inspiration for the film 'The Man Without a Face". Yet, Mel Gibson is generally associated with several attributes, such as "a movie star", "a controversial person", "a prejudiced individual", or "a tough man" rather than a single category. This folklore, therefore, could not be translated into an unambiguous code.

Instead, only fictitious claims that both researchers translated to the same code, or to two codes that were synonymous with one another, were retained. This procedure uncovered an initial set of 715 different codes.

\subsection{Amalgamation and Validation of Codes}

Four psychologists, including the two researchers, distributed the 715 codes, each printed on a card, into piles of overlapping codes. If all four researchers distributed two cards into the same pile, the corresponding codes were then amalgamated. This procedure uncovered 81 amalgamated codes. 
Next, to validate these amalgamated codes, two researchers, in isolation from each other, classified another set of 100 fictitious claims into these piles - at least after the specific nouns and verbs of these claims were converted to broader categories. Either one or both researchers felt that some of these additional codes did not align to any of the piles. These codes were instead classified into their own piles. This procedure was repeated four more times until saturation was reached.

The two researchers assigned $88 \%$ of these 500 additional claims to the same piles. After considerable discussion, this percentage increased to $100 \%$. Overall, this procedure added 7 more amalgamated codes to the initial set of 81 aggregated codes. The first column of Table 2 presents the final set of amalgamated codes. The second column of Table 2 presents a sample folklore that corresponds to this amalgamated code. Each of these amalgamated codes, putatively, reflects a distinct misguided belief or contrived anecdote.

Table 2. List of aggregated codes and the corresponding themes

\begin{tabular}{|c|c|c|}
\hline Specific codes & Sample claims & Broader themes \\
\hline & & Need for closure \\
\hline $\begin{array}{l}\text { If authorities are too powerful, } \\
\text { many hazards become pronounced }\end{array}$ & $\begin{array}{l}\text { Police radar gun accidentally causes } \\
\text { a missile to lock onto it. }\end{array}$ & $\begin{array}{l}\text { Some authorities are unhelpful and, } \\
\text { hence, their decrees can be rejected. }\end{array}$ \\
\hline $\begin{array}{l}\text { The authorities are incompetent, } \\
\text { unintelligent, and ignorant }\end{array}$ & $\begin{array}{l}\text { Hoping to attract the singer's } \\
\text { attention, George W. Bush waved at } \\
\text { Stevie Wonder. }\end{array}$ & \\
\hline $\begin{array}{l}\text { The authorities are unnecessarily } \\
\text { strict, cautious, and inefficient }\end{array}$ & $\begin{array}{l}\text { California law requires state } \\
\text { residents to obtain hunting licenses } \\
\text { before setting mousetraps. }\end{array}$ & \\
\hline The government is uncaring & $\begin{array}{l}\text { The Brazilian Congress is about to } \\
\text { vote on a bill that would reduce the } \\
\text { size of the Amazon rain forest by } \\
50 \% \text {. }\end{array}$ & \\
\hline $\begin{array}{l}\text { The judgments of authorities and } \\
\text { critics are unfounded }\end{array}$ & $\begin{array}{l}\text { A man stuck in cat door without his } \\
\text { pants is mistaken for a work of art. }\end{array}$ & \\
\hline $\begin{array}{l}\text { People or organizations that seem } \\
\text { charitable, helpful, or benevolent } \\
\text { are not entirely moral }\end{array}$ & $\begin{array}{l}\text { Walt Disney was dishonorably } \\
\text { discharged from the military. }\end{array}$ & $\begin{array}{l}\text { Immoral behavior is prevalent, even } \\
\text { in people or communities that seem } \\
\text { charitable and altruistic }\end{array}$ \\
\hline Illicit drug use is prevalent & $\begin{array}{l}\text { The personalities of the dwarf } \\
\text { characters in Snow White and the } \\
\text { Seven Dwarfs represent the seven } \\
\text { stages of cocaine addiction. }\end{array}$ & \\
\hline Racism and other prejudices are rife & $\begin{array}{l}\text { Donald Duck shouts a racial epithet } \\
\text { at Daffy Duck. }\end{array}$ & \\
\hline $\begin{array}{l}\text { Corporations are immoral and } \\
\text { mercenary }\end{array}$ & $\begin{array}{l}\text { The four major U.S. credit bureaus } \\
\text { will be allowed to share your credit } \\
\text { information with anyone who } \\
\text { requests it after July } 1 \text { unless you } \\
\text { specifically request to be excluded. }\end{array}$ & $\begin{array}{l}\text { Success often indicates a person, } \\
\text { group, or organization is immoral or } \\
\text { excluded }\end{array}$ \\
\hline $\begin{array}{l}\text { Corporations and other powerful } \\
\text { movements are sneaky, } \\
\text { manipulative, and inaccessible }\end{array}$ & $\begin{array}{l}\text { Casinos pump extra oxygen onto } \\
\text { the gaming floors during the } \\
\text { early-morning hours to keep tired } \\
\text { patrons from heading to bed. }\end{array}$ & \\
\hline Luxury brands are immoral & $\begin{array}{l}\text { The ocean liner QE2 uses a gallon } \\
\text { of fuel for every six inches she } \\
\text { travels. }\end{array}$ & \\
\hline $\begin{array}{l}\text { Morality and success are mutually } \\
\text { exclusive }\end{array}$ & $\begin{array}{l}\text { Law students failed their California } \\
\text { bar exams because they stopped to }\end{array}$ & \\
\hline
\end{tabular}


assist a stricken classmate.

The elite are immoral

The elite are eccentric

Because attractive people are obsessed with their appearance, they may engage in hazardous or unusual behaviors

Disadvantaged people are often mistreated

Rivals and foreigners are immoral or bizarre

Misbelievers are immoral

Homosexuals are immoral

Religious or spiritual communities are enigmatic and insidious

The items of foreign or unfamiliar communities are hazardous Strangers are immoral

People who are reclusive cannot be trusted

Modest hazards can evolve into major catastrophes

Unhealthy or disgusting items are contagious and need to be avoided

Tragedies and hazards can be
predicted

Tragedies are restricted to specific people or groups

Cues are always informative

A circus dwarf died when he bounced off a trampoline into the mouth of a hippopotamus.

During wartime, the seal of the
Celebrity is hospitalized to have gerbil removed from his anus

Walt Disney's will specified that a substantial bequest be awarded to the first man to become pregnant or bear a child.

Woman dies after visiting too many tanning parlors in one day.

'Handicap' came from 'cap in hand,' referring to a disabled person's need to subsist through begging.

Roast fetus is the latest gourmet
food in Taiwan.

Atheist Madalyn Murray O'Hair is circulating a petition to ban religious broadcasting from American airwaves.

Man is secretly anesthetized and sodomized by his gay roommate.

A group known as 'The Second Coming Project' is seeking to clone Jesus from the DNA of holy relics.

Cactus explodes and spews baby tarantulas everywhere.

Rape victims are lured from malls with the promise of appearing in pizza commercials.

One of the boys who murdered his classmates at Columbine High School prepared by designing new computer game levels that resembled his school and peopling them with representations of his classmates.

Hospital janitor accidentally kills patients by unplugging their life-support systems.

$\mathrm{HIV}+$ blood has been slipped into ketchup dispensers in fast food restaurants.

A Nostradamus prophecy foretold the Space Shuttle Columbia disaster.

Tragedies and threats are predictable
Unfamiliar behaviors, people, or objects are hazardous or disgusting and should be avoided President of the United States is 
modified so that the eagle's head faces the opposite direction.

The authorities are transparent rather than veiled

A policeman solicited by a hooker must answer truthfully when asked 'Are you a cop?'

Trivial acts can prevent hazards
You can effectively establish copyright of your work by mailing a copy to yourself, then retaining the sealed, postmarked envelopes.

Moral people can be protected by religious or spiritual forces

Not permitted to celebrate Christmas in Meulaboh, Christians gathered on a high hill nearby and thus were spared when the tsunami wiped out the city.

Tragedies can be ascribed to an evil force

A cursed mummy sent the Titanic to its watery grave.

Blends of categories are unhealthy
or unsuitable
People who are associated with
each other tend to be similar
Religious or spiritual communities
are distinct from secular
communities

Religious or spiritual acts can be explained by scientific or common knowledge

Some guidelines are actually legislated

A mixture of Mentos and
Coca-Cola killed two Brazilian
children

Authors Dr. Seuss and Kurt Vonnegut, Jr. were college classmates and fraternity brothers.

Someone is in a race to collect the e-signatures of 300 people who believe in God before someone else collects 300 e-signatures from those who do not.

The red dot on a Hindu woman's forehead is nothing more than an indicator of her marital status.

Sending cash through the U.S. mail is illegal.
If individuals undertake specific activities, they can manipulate other people

People are impressionable

The qualities and capabilities of other people are transparent

\section{Coca-Cola and aspirin is an} aphrodisiac

A pair of hoaxsters once led hundreds of gullible New Yorkers into participating in a scheme to saw Manhattan Island in half.

The size of a man's nose, hands, or feet is a reliable indicator of the size of his penis.

\begin{tabular}{ll}
\hline $\begin{array}{l}\text { Acts that are regarded as immoral } \\
\text { are actually beneficial or respectful }\end{array}$ & $\begin{array}{l}\text { According to a university study, } \\
\text { fellatio may significantly decrease } \\
\text { the risk of breast cancer in women. }\end{array}$ \\
$\begin{array}{l}\text { Products that are supposed to be } \\
\text { healthy or hygienic can actually be } \\
\text { hazardous }\end{array}$ & $\begin{array}{l}\text { Ordinary use of waterproof } \\
\text { sunscreen can cause blindness. }\end{array}$ \\
$\begin{array}{l}\text { Unsuitable acts, undertaken to only } \\
\text { a limited extent, are not hazardous }\end{array}$ & $\begin{array}{l}\text { Dropped food remains germ-free if } \\
\text { picked up within five seconds. }\end{array}$ \\
\hline
\end{tabular}

\section{Tragedies and threats can be} prevented

\author{
All items belong to exclusive, \\ homogenous, and enduring \\ categories
}

Other people can be readily manipulated

\author{
Some acts that are perceived as \\ deviant are actually beneficial or \\ inconsequential and thus \\ acceptable - as well as vice versa
}




$\begin{array}{ll}\begin{array}{l}\text { Other groups are unnecessarily } \\ \text { cautious and judgmental }\end{array} & \begin{array}{l}\text { Finland once banned Donald Duck } \\ \text { because he wears no pants. }\end{array} \\ \begin{array}{l}\text { Some people or organizations are } \\ \text { unnecessary sensitive and righteous }\end{array} & \begin{array}{l}\text { An organization called Citizens } \\ \text { Against Breast-Feeding is } \\ \text { petitioning Congress to outlaw } \\ \text { breast-feeding. }\end{array}\end{array}$

Victims are often responsible for the tragedies they experience

Immoral acts will ultimately be punished

If people who are disadvantaged or dead are not treated respectfully, the perpetrators will be punished

Moral acts can be rewarded unexpectedly

Moral people eventually prevail

Suitable acts now may be rewarded many years in the future

The proficiency of large
corporations, compared to
individuals or small collectives of
people, is overestimated

Advances in knowledge and science are overestimated

Segments of society that seem naïve are actually insightful

People or objects can derive power from ethereal forces

The elite are especially vulnerable

Power is distributed across society
Dr. Joseph Guillotine invented the guillotine and was later executed with one of those machines.

In the wake of a major earthquake, a car thief WAS found crushed in the vehicle he had stolen.

Ghosts of two murdered teen girls return to kill and skin parents who failed to tell their subsequent son of the girls' existence.

A stranger who stopped to change a tire on a disabled limo was rewarded for his efforts when the vehicle's passenger, Donald Trump, paid his mortgage

Mr. and Mrs. Leland Stanford decided to found their own university after being rebuffed in an attempt to donate a building to Harvard.

An Oregon girl's message-in-a-bottle was found by a boy in Hawaii.

A group of former General Motors workers furtively produced 1957 Chevrolet automobiles on its own for ten years.

A video clip shows a NASA studio-produced 'outtake' of the first moon landing.

The pro-school prayer poem "The New School Prayer" was written by a schoolchild.

The spiral stairway at Santa Fe's Loretto Chapel miraculously stands despite having no discernible means of support

Singer Britney Spears committed
suicide at the Promises clinic in October 2007.

The U.S. Constitution requires presidential and vice-presidential candidates to be from different states.

\section{Overestimation of morality}

People receive the punishments and rewards they deserve
People or communities that do not seem to be powerful or competent are more proficient than society realizes and vice versa
Overall, everyone is granted the same proportion of privileges and challenges




\begin{tabular}{|c|c|}
\hline Wealth diminishes wellbeing & $\begin{array}{l}\text { Soon after winning the largest ever } \\
\text { Megabucks jackpot, the new } \\
\text { multi-millionaire died a violent } \\
\text { death. }\end{array}$ \\
\hline $\begin{array}{l}\text { Mothers will sacrifice anything to } \\
\text { help their children }\end{array}$ & $\begin{array}{l}\text { Mother reveals in posthumous letter } \\
\text { to son that she had had only one eye } \\
\text { because she had donated the other } \\
\text { eye to him. }\end{array}$ \\
\hline $\begin{array}{l}\text { Even competitors sometimes } \\
\text { cooperate with each other }\end{array}$ & $\begin{array}{l}\text { Tenor José Carreras recovered from } \\
\text { leukemia with the assistance of a } \\
\text { foundation secretly started by his } \\
\text { bitter rival, Plácido Domingo. }\end{array}$ \\
\hline $\begin{array}{l}\text { Inexpensive, indulgent, or } \\
\text { expedient items can be very } \\
\text { unhealthy or hazardous }\end{array}$ & $\begin{array}{l}\text { McDonald's hamburgers contain } \\
\text { worm meat. }\end{array}$ \\
\hline Illicit drug use is very hazardous & $\begin{array}{l}\text { Students on LSD trip stare at the } \\
\text { sun until blinded. }\end{array}$ \\
\hline Drug users are immoral & $\begin{array}{l}\text { Drug addicts are leaving HIV-laden } \\
\text { needles in pay phone coin slots. }\end{array}$ \\
\hline $\begin{array}{l}\text { Sexual urges or acts can be } \\
\text { hazardous }\end{array}$ & $\begin{array}{l}\text { A lad electrocutes himself with a } \\
\text { cow's heart with which he had been } \\
\text { pleasuring himself. }\end{array}$ \\
\hline $\begin{array}{l}\text { Sexual beings are unintelligent or } \\
\text { immoral }\end{array}$ & $\begin{array}{l}\text { Scientists have discovered a vast } \\
\text { reef of floating condoms in the } \\
\text { Pacific Ocean. }\end{array}$ \\
\hline $\begin{array}{l}\text { To avoid pregnancy, girls need to } \\
\text { be vigilant }\end{array}$ & $\begin{array}{l}\text { Girl is impregnated by sperm in } \\
\text { swimming pool. }\end{array}$ \\
\hline Children need to be controlled & $\begin{array}{l}\text { Child drowns after jumping into the } \\
\text { ocean to see SpongeBob Square } \\
\text { Pants }\end{array}$ \\
\hline $\begin{array}{l}\text { Vacations can be hazardous or } \\
\text { depressing }\end{array}$ & $\begin{array}{l}\text { The suicide rate increases } \\
\text { significantly during the winter } \\
\text { holiday season. }\end{array}$ \\
\hline
\end{tabular}

Skills and qualities are malleable

Teacher turns around a particularly unlovable child named Teddy Stoddart who later becomes a doctor.

If individuals are able to control primal urges or impulses, benefits are likely to unfold In some contexts, people can be trusted unconditionally are likely to unfold

\section{Inflation of capabilities}

A few minor acts or events may be sufficient to overcome limitations in your attributes, reputations, or resources later

Healthy options can be remarkably Eating carrots improves vision. beneficial

Trivial items can be valuable

Man buys old motorcycle and then discovers the item was once owned by Elvis Presley.

Relative to previous generations, people are more enlightened now

When the bathtub was introduced to the U.S. in the mid-1800s, its Our community is more advanced popularity was hindered by the belief that taking baths was injurious to a person's health

Deprived communities could not Cleveland Indians second baseman survive without our assistance Joe Gordon once deliberately struck out to prevent rookie Larry 


\begin{tabular}{ll} 
& $\begin{array}{l}\text { Doby-one of the few African } \\
\text { Americans at the time- from } \\
\text { looking incompetent }\end{array}$ \\
$\begin{array}{l}\text { Religious or spiritual communities } \\
\text { are archaic and uninformed }\end{array}$ & $\begin{array}{l}\text { Alabama redefined the value of pi } \\
\text { to } 3 \text { to bring it in line with Biblical } \\
\text { precepts. }\end{array}$ \\
\hline $\begin{array}{l}\text { The world is improving and } \\
\text { wonderful opportunities are } \\
\text { imminent }\end{array}$ & $\begin{array}{l}\text { Web site will reveal an } \\
\text { "astounding" discovery to the world } \\
\text { on } 8 \text { March 2003. }\end{array}$ \\
$\begin{array}{l}\text { Concealed knowledge about } \\
\text { unexplored opportunities may soon } \\
\text { be unveiled }\end{array}$ & $\begin{array}{l}\text { Make money by learning the secrets } \\
\text { of the World Currency Cartel. }\end{array}$ \\
$\begin{array}{l}\text { Groups are powerful enough to } \\
\text { redress injustice or immorality }\end{array}$ & $\begin{array}{l}\text { The collection of a million } \\
\text { signatures on a petition will spur the } \\
\text { Nobel Foundation into revoking the } \\
\text { portion of the 1994 Nobel Peace }\end{array}$ \\
$\begin{array}{l}\text { Prize awarded to Palestinian leader } \\
\text { Yasser Arafat. }\end{array}$ \\
$\begin{array}{l}\text { John F. Kennedy triggered a } \\
\text { precipitous decline in the sales of } \\
\text { men's hats by appearing hatless at } \\
\text { his 1961 inauguration. }\end{array}$ \\
$\begin{array}{l}\text { Woman named Emily takes revenge } \\
\text { Resourceful individuals are }\end{array}$ \\
$\begin{array}{l}\text { Wowerful enough to redress } \\
\text { injustice or immorality }\end{array}$ & $\begin{array}{l}\text { on her cheating husband by } \\
\text { advertising his infidelities on a } \\
\text { billboard }\end{array}$ \\
\hline
\end{tabular}

Celebrated brands are enduring
Existing symbols and artifacts
embody real and momentous events
in the past

\begin{tabular}{ll}
\hline The modern world is immoral & $\begin{array}{l}\text { A reality show on NBC will feature } \\
\text { women being pursued through the } \\
\text { brush by rapists. }\end{array}$ \\
Changes are disrespectful & $\begin{array}{l}\text { 'Xmas' is a modern, disrespectful } \\
\text { abbreviation of the word } \\
\text { 'Christmas'. }\end{array}$ \\
Technology and progress is & $\begin{array}{l}\text { Cell phone calls from particular } \\
\text { cellular phone numbers can cause } \\
\text { brain hemorrhage and death. }\end{array}$ \\
hazardous & $\begin{array}{l}\text { Growth hormones injected into } \\
\text { chicken wings cause ovarian cysts } \\
\text { in women. }\end{array}$ \\
hazardous & $\begin{array}{l}\text { Fun-loving teens are lobbing lit } \\
\text { gasoline-soaked rags into cars } \\
\text { halted at red lights in a deadly game } \\
\text { called spunkball. }\end{array}$ \\
Younger generations today are &
\end{tabular}
cryonic storage.

Death of an infant in an auto accident led to the invention of "Baby on Board" signs.

A reality show on NBC will feature
The world is gradually progressing or could improve dramatically in the future

\section{Overestimation of stability in values}

People or practices that are valued now will be cherished forever

Entrenched practices are better than alternatives 


\subsection{Broader Themes}

The procedure that was applied to generate these amalgamated codes was then utilized to derive broader themes from the 88 amalgamated codes. Apart from nine of the amalgamated codes, the two researchers generated the same piles. Discussions were conducted to reconcile any disagreement between the researchers. During these discussions, the researchers also articulated and clarified the theme that all the cards in each pile shared. The final column of Table 2 enumerates the 19 themes that emerged from this procedure.

Finally, the researchers, in isolation from each other, classified these 19 broader themes into one of the four constellations of biases, specified in Table 1. The third column of Table 2 arranges the themes into sets that correspond to the same bias. One of the themes - "If individuals are able to control primal urges or impulses, benefits are likely to unfold"-generated some disagreement. In particular, three of the researchers classified this theme into the biases that relate to overestimation of morality. These argued this theme implies that suppressing personal urges to serve their community indicates that morality is encouraged. In contrast, one of the researchers felt this theme to not align to any of the four constellations.

\section{Discussion}

Fictitious information, contrived anecdotes, and misguided beliefs permeate social media and other modes of communication. Indeed, the website snopes.com has uncovered thousands of folklores that have been shown to be fictitious. These fictitious claims are sometimes innocuous but can evolve into unjust, destructive, or even violent behavior (e.g., Saucier et al., 2009).

As this paper shows, when people are especially motivated to enhance their emotions, consistent with self-discrepancy theory (Higgins, 1987) and the meaning maintenance model (Heine et al., 2006), four constellations of biases are especially likely to alleviate negative emotions and foster positive emotions. In particular, individuals tend to overestimate the clarity of their duties, the morality of their community, the capabilities they have acquired, and the stability of societal values. This study showed that most fictitious claims epitomize one of these four sets of biases. These results imply that people often fabricate, disseminate, or embrace folklores to fulfill the conditions that improve their emotions.

First, 9 of the 19 themes that were uncovered comprise fictitious claims that justify or fulfill a need for closure. Specifically, three of these nine themes, including "Some authorities are unhelpful and, hence, their decrees can be rejected", "Immoral behavior is prevalent, even in people or communities that seem charitable and altruistic", and "Success often indicates a person, group, or organization is immoral or excluded", indicate that most authorities or powerful individuals are illegitimate. These claims, therefore, justify the tendency of people to disregard all but one or two authorities or ideologies, epitomizing a need for closure (Kruglanski et al., 2002) and clarifying which duties they need to follow.

Furthermore, another three of these nine themes, specifically "Unfamiliar behaviors, people, or objects are hazardous or disgusting and should be avoided", "Tragedies and threats are predictable", and "Tragedies and threats can be prevented", vindicate the preference of some individuals to gravitate to predictable settings (Webster \& Kruglanski, 1994) in which their obligations are not ambiguous. Two of these nine themes, including "All items belong to exclusive, homogenous, and enduring categories" and "Other people can be readily manipulated", demonstrate that people, and hence their demands, are not unpredictable (cf., Webster \& Kruglanski, 1994). Finally, the theme "Some acts that are perceived as deviant are actually beneficial or inconsequential and thus acceptable" indicates that some deviations from duties may be accepted, diminishing anxiety and agitation (Higgins, 1987).

Second, 5 of the 19 themes that were unearthed correspond to fictitious claims that underscore the morality and justice that pervades society. One of these themes emphasizes the prevalence of equity (Adams, 1963) or a just world (Lerner, 1980): "People receive the punishments and rewards they deserve". In contrast, two of the themes, including "People or communities that do not seem to be powerful or competent are more proficient than society realizes and vice versa" and "Overall, everyone is granted the same proportion of privileges and challenges", highlight that, overall, equality is prevalent. Equality, unlike equity, implies that individuals enjoy similar levels of aggregate resources (Bremner, 2008), regardless of their contributions. Furthermore, the theme "In some contexts, people can be trusted unconditionally" emphasizes the benevolence of some people. Finally, the theme "If individuals are able to control primal urges or impulses, benefits are likely to unfold" may indicate that communal interests, rather than egocentric pursuits, are encouraged and thus prevalent.

Third, 3 of the 19 themes that emerged revolve around fictitious claims that facilitate self-enhancement biases. For the theme "A few minor acts or events may be sufficient to overcome limitations in your attributes, 
reputations, or resources later", the self is limited to the individual. For the theme "Our community is more advanced than other communities", the self is extended to the community, sometimes called a collective self-construal (e.g., Rice, Clayton, Trafimow, Keller, \& Hughes, 2009). Finally, for the theme "The world is gradually progressing or could improve dramatically in the future", the self is extended to all humanity, analogous to the concept of humanity esteem (Luke \& Maio, 2009). Indeed, as research shows, when individuals perceive humanity favorably, their self-esteem rises as well (Luke \& Maio, 2009).

Fourth, 2 of the 19 themes that were identified either demonstrate or champion the stability of values over time. These themes entail "People or practices that are valued now will be cherished forever" and "Entrenched practices are better than alternatives".

\subsection{Implications of these Findings}

These findings indicate that people may contrive, disseminate, and embrace fictitious claims to cultivate the four conditions that foster pleasant emotions. As this conclusion implies, policies or practices that foster these conditions may diminish the likelihood of fictitious, and potentially destructive, folklores.

To illustrate, the mood of managers will affect the demands they impose. When managers are happy, they are more inclined to encourage acts of altruism (Dunn, Aknin, \& Norton, 2008). As this happiness dissipates, they may not encourage, and could even punish, acts of altruism. Their employees, therefore, are not certain which duties to fulfill and, therefore, may experience a need for closure. Initiatives that stabilize the mood of managers may thus diminish this uncertainty about duties and prevent this need for closure.

Furthermore, many initiatives could also override the inclination of people to overestimate the level of morality and justice in society. For example, when inequality in income subsides, individuals become more trusting and cooperative (Oishi, Kesebir, \& Diener, 2011). People feel they will be supported, instead of punished, provided they fulfill their duties. Their need to inflate the level of morality and justice in society should abate.

In addition, other initiatives could diminish the tendency of people to inflate their capabilities. For instance, when the development of knowledge and skills, instead of merely the achievement of outcomes, is rewarded, individuals are more likely to feel they can enhance their underlying competence, intelligence, and capabilities (Robins \& Pals, 2002), called an incremental theory of malleability or a growth mindset (Dweck, Chui, \& Hong, 1995). After they adopt this mindset, people are more responsive to feedback and more likely to develop their capabilities (for a review, see Dweck, 2006). Their need to overestimate their capabilities diminishes.

Finally, some initiatives could temper the inclination of individuals to overestimate the stability of values in society. To illustrate, CEOs often change the strategies and values of their organization. According to recent studies, if CEOs trusted their intuition, their preferences and values would not shift as erratically (Lee, Amir, \& Ariely, 2009; Nordgren \& Dijksterhuis, 2009). The achievements that are valued would seem more consistent over time. Employees would not feel as tempted to inflate the stability of values that permeate their society or workplace.

Indeed, in these stable workplaces, individuals are more inclined to feel their own values and identity would endure. According to socioemotional selectivity theory (Carstensen, 1995), these individuals should thus be motivated to accumulate knowledge, diminishing the likelihood of biases.

Nevertheless, an important limitation of this study should be acknowledged. In particular, subjective impressions, rather than objective criteria, governed the classification of fictitious claims into four constellations. Future research is needed to confirm that each constellation does indeed correspond to one underlying bias. For example, researchers should demonstrate that any exercise that nullifies one bias should decrease the degree to which all the corresponding fictitious claims are perceived as viable or desirable.

In short, a variety of initiatives could be introduced to diminish the likelihood of biased assumptions and fictitious claims. These initiatives would also enhance the emotions of people sustainably, reducing the incidence of mental illness. Finally, the themes that emerged from this study could also be utilized by advertisers and marketers to optimize their slogans and campaigns. Slogans and campaigns that align to one of the 88 amalgamated codes that were identified are especially likely to be embraced.

\section{References}

Adams, J. S. (1963). Toward an understanding of inequity. Journal of Abnormal and Social Psychology, 67, 422-436. http://dx.doi.org/10.1037/h0040968 
Arndt, J., Greenberg, J., \& Cook, A. (2002). Mortality salience and the spreading activation of worldview-relevant constructs: Exploring the cognitive architecture of terror management. Journal of Experimental Psychology: General, 131, 307-324. http://dx.doi.org/10.1037/0096-3445.131.3.307

Boldero, J. M., Moretti, M. M., Bell, R. C., \& Francis, J. J. (2005). Self-discrepancies and negative affect: A primer on when to look for specificity, and how to find it. Australian Journal of Psychology, 57, 139-147. http://dx.doi.org/10.1080/00049530500048730

Boldero, J., \& Francis, J. (1999). Ideals, oughts, and self-regulation: Are there qualitatively distinct self-guides? Asian Journal of Social Psychology, 2, 343-355. http://dx.doi.org/10.1111/1467-839X.00044

Bosson, J. K., Brown, R. P., Zeigler-Hill, V., \& Swann, W. B., Jr. (2003). Self-enhancement tendencies among people with high explicit self-esteem: The moderating role of implicit self-esteem. Self and Identity, 2, 169-187. http://dx.doi.org/10.1080/15298860390208801

Bowen, G. A. (2008). Naturalistic inquiry and the saturation concept: A research note. Qualitative Research, 8 , 137-152. http://dx.doi.org/10.1177/1468794107085301

Braun, V., \& Clarke, V. (2006). Using thematic analysis in psychology. Qualitative Research in Psychology, 3, 77-101. http://dx.doi.org/10.1191/1478088706qp063oa

Bremner, C. A. (2008). Valuing distributive equality. Queen's University.

Carstensen, L. L. (1995). Evidence for a life-span theory of socioemotional selectivity. Current Directions in Psychological Science, 4, 151-156. http://dx.doi.org/10.1111/1467-8721.ep11512261

Carstensen, L. L. (2006). The influence of a sense of time on human development. Science, 312, 1913-1915. http://dx.doi.org/ 10.1126/science.1127488

Carstensen, L. L., \& Fredrickson, B. L. (1998). Influence of HIV status and age on cognitive representations of others. Health Psychology, 17, 494-503. http://dx.doi.org/10.1037/0278-6133.17.6.494

Carstensen, L. L., Isaacowitz, D. M., \& Charles, S. T. (1999). Taking time seriously: A theory of socioemotional selectivity. American Psychologist, 54, 165-181. http://dx.doi.org/10.1037/0003-066X.54.3.165

Carver, C. S., \& Scheier, M. F. (1990). Origins and functions of positive and negative affect: A control-process view. Psychological Review, 97, 19-35. http://dx.doi.org/10.1037/0033-295X.97.1.19

Charles, S. T., Mather, M., \& Carstensen, L. L. (2003). Aging and emotional memory: The forgettable nature of negative images for older adults. Journal of Experimental Psychology: General, 132, 310-324. http://dx.doi.org/10.1037/0096-3445.132.2.310

Correia, I., Kamble, S. V., \& Dalbert, C. (2009). Belief in a just world and well-being of bullies, victims and defenders: a study with Portuguese and Indian students. Anxiety, Stress, and Coping, 22, 497-508. http://dx.doi.org/10.1080/10615800902729242.

Croyle, R. T., Loftus, E. F., Barger, S. D., Sun, Y., Hart, M., \& Gettig, J. (2006). How well do people recall risk factor test results? Accuracy and bias among cholesterol screening participants. Health Psychology, 25, 425-432. http://dx.doi.org/10.1037/0278-6133.25.3.425

Dalbert, C. (2001). The justice motive as a personal resource: Dealing with challenges and critical life events. New York: Plenum.

Derryberry, D., \& Reed, M. A. (1998). Anxiety and attentional focusing: Trait, state and hemispheric influences. Personality and Individual Differences, 25, 745-761. http://dx.doi.org/10.1016/S0191-8869(98)00117-2

Deutsch, M. (1975). Distributive justice: A social-psychological perspective. New Haven, CT: Yale University Press.

DeWall, C. N., Visser, P. S., \& Levitan, L. C. (2006). Openness to attitude change as a function of temporal perspective. Personality and Social Psychology Bulletin, 32, 1010-1023. http://dx.doi.org/10.1177/0146167206288009

Dunn, E. W., Aknin, L. B., \& Norton, M. I. (2008). Spending money on others promotes happiness. Science, 319, 1687-1688. http://dx.doi.org/10.1126/science.1150952

Dweck, C. S. (2006). Mindset: The new psychology of success. New York, NY: Random House.

Dweck, C., Chui, C., \& Hong, Y. (1995). Implicit theories and their role in judgments and reactions: A world from two perspectives. Psychological Inquiry, 6, 267-285. http://dx.doi.org/10.1207/s15327965pli0604_1 
Folkman, S., Lazarus, R. S., Gruen, R. J., \& DeLongis, A. (1986). Appraisal, health status and psychological symptoms. Journal of Personality and Social Psychology, 50, 571-579.

Heine, S. J., Proulx, T., \& Vohs, K. D. (2006). Meaning maintenance model: On the coherence of human motivations. Personality and Social Psychology Review, 10, 88-110.

Higgins, E. T. (1987). Self-discrepancy: A theory relating self and affect. Psychological Review, 94, 319-340. http://dx.doi.org/10.1037/0033-295X.94.3.319

Higgins, E. T. (1989). Self-discrepancy theory: What patterns of self-beliefs cause people to suffer? In L. Berkowitz (Ed.), Advances in experimental social psychology (Vol. 22, pp. 93-136). New York: Academic Press.

Higgins, E. T. (1997). Beyond pleasure and pain. American Psychologist, 52, 1280-1300. http://dx.doi.org/10.1037/0003-066X.52.12.1280

Higgins, E. T. (1999). When do self-discrepancies have specific relations to emotions? The second-generation question of Tangney, Niedenthal, Covert, and Barlow (1998). Journal of Personality and Social Psychology, 77, 1313-1317. http://dx.doi.org/10.1037/0022-3514.77.6.1313

Janoff-Bulman, R., Timko, C., \& Carli, L. L. (1985). Cognitive biases in blaming the victim. Journal of Experimental Social Psychology, 21, 161-177. http://dx.doi.org/10.1016/0022-1031(85)90013-7

Kazen, M., Kaschel, R., \& Kuhl, J. (2008). Individual differences in intention initiation under demanding conditions: Interactive effects of state vs. action orientation and enactment difficulty. Journal of Research in Personality, 42, 693-715. http://dx.doi.org/10.1016/j.jrp.2007.09.005

King, J. (2010). Conspiracy theories. Summersdale.

Kruglanski, A. W., Shah, J. Y., Pierro, A., \& Mannetti, L. (2002). When similarity breeds content: Need for closure and the allure of homogenous and self-resembling groups. Journal of Personality and Social Psychology, 83, 648-662. http://dx.doi.org/10.1037/0022-3514.83.3.648

Kruglanski, A. W., \& Webster, D. M. (1996). Motivated closing of the mind: "Seizing" and "freezing." Psychological Review, 103, 263-283. http://dx.doi.org/10.1037/0033-295X.103.2.263

Kuhl, J. (2000). A functional-design approach to motivation and volition: The dynamics of personality systems interactions. In M. Boekaerts, P. R. Pintrich, \& M. Zeidner (Eds.), Self-regulation: Directions and challenges for future research (pp. 111-169). New York: Academic Press.

Lee, L., Amir, O., \& Ariely, D. (2009). In search of homo economicus: Cognitive noise and the role of emotion in preference consistency. Journal of Consumer Research, 36, 173-187. http://dx.doi.org/10.1086/597160

Lerner, M. J. (1980). The belief in a just world: A fundamental delusion. New York: Plenum Press.

Lewicki, P. (1983). Self-image bias in person perception. Journal of Personality \& Social Psychology, 45, 384-393. http://dx.doi.org/10.1037/0022-3514.45.2.384

Luke, M. A., \& Maio, G. R. (2009). Oh the humanity! Humanity-esteem and its social importance. Journal of Research in Personality, 43, 586-601. http://dx.doi.org/10.1016/j.jrp.2009.03.001

Mather, M., \& Carstensen, L. L. (2003). Aging and attentional biases for emotional faces. Psychological Science, 14, 409-415. http://dx.doi.org/10.1111/1467-9280.01455

Mather, M., \& Carstensen, L. L. (2005). Aging and motivated cognition: The positivity effect in attention and memory. Trends in Cognitive Sciences, 9, 496-502. http://dx.doi.org/10.1016/j.tics.2005.08.005

Nordgren, L. F., \& Dijksterhuis, A. (2009). The devil is in the deliberation: Thinking too much reduces preference consistency. Journal of Consumer Research, 36, 39-46. http://dx.doi.org/10.1086/596306

Oishi, S., Kesebir, S., \& Diener, E. (2011). Income inequality and happiness. Psychological Science, 22, 1095-1100. http://dx.doi.org/10.1177/0956797611417262

Proulx, T., \& Heine, S. J. (2006). Death and black diamonds: Meaning, mortality, and the Meaning Maintenance Model. Psychological Inquiry, 17, 309-318.

Proulx, T., \& Heine, S. J. (2008). The case of the transmogrifying experimenter: Affirmation of a moral schema following implicit change detection. Psychological Science, 19, 1294-1300. http://dx.doi.org/0.1111/j.1467-9280.2008.02238.x 
Proulx, T., \& Heine, S. J. (2009). Connections from Kafka: Exposure to meaning threats improves implicit learning of an artificial grammar. Psychological Science, 20, 1125-1131. http://dx.doi.org/10.1111/j.1467-9280.2009.02414.x

Pruzan, K., \& Isaacowitz, D. M. (2006). An attentional application of socioemotional selectivity theory in college students. Social Development, 15, 326-338. http://dx.doi.org/10.1046/j.1467-9507.2006.00344.x

Randles, D., Proulx , T., \& Heine, S. J. (2010). Turn-frogs and careful-sweaters: Non-conscious perception of incongruous word pairings provokes fluid compensation. Journal of Experimental Social Psychology, 47, 246-249. http://dx.doi.org/10.1016/j.jesp.2010.07.020

Rice, S., Clayton, K. D., Trafimow, D., Keller, D., \& Hughes, J. (2009). The effects of private and collective self-priming on visual search: Taking advantage of organized contextual stimuli. British Journal of Social Psychology, 48, 467-486. http://dx.doi.org/10.1348/014466608X354580

Robins, R. W., \& Pals, J. L. (2002). Implicit self-theories in the academic domain: Implications for goal orientation, attributions, affect, and self-esteem change. Self and Identity, 1, 313-336. http://dx.doi.org/10.1080/15298860290106805

Roeper, R. (2008). Debunked! Conspiracy theories, urban legends, and evil plots of the 21st century. Chicago Review Press.

Saucier, G., Akers, L. G., Shen-Miller, S., Knezevic, G., \& Stankov, L. (2009). Patterns of thinking in militant $\begin{array}{lllll}\text { extremism. Perspectives on Psychological } & \text { Science, } & 4, & \text { 256-271. }\end{array}$ http://dx.doi.org/10.1111/j.1745-6924.2009.01123.x

Scott, L. O., \& Hara, M. W. (1993). Self-discrepancies in clinically anxious and depressed university students. Journal of Abnormal Psychology, 102, 282-287. http://dx.doi.org/10.1037/0021-843X.102.2.282

Strauman, T. J. (1989). Self-discrepancies in clinical depression and social phobia: Cognitive structures that underlie emotional disorders? Journal of Abnormal Psychology, 98, 14-22. http://dx.doi.org/10.1037/0021-843X.98.1.14

Taylor, S. E., \& Brown, J. (1988). Illusion and well-being: A social psychological perspective on mental health. Psychological Bulletin, 103, 193-210. http://dx.doi.org/10.1037/0033-2909.103.2.193

Van Hiel, A., Pandelaere, M., \& Duriez, B. (2004). The impact of need for closure on conservative beliefs and racism: Differential mediation by authoritarian submission and authoritarian dominance. Personality \& Social Psychology Bulletin, 30, 824-837. http://dx.doi.org/10.1177/014616720426433

Van Tongeren, D., \& Green, J. D. (2010). Combating meaninglessness: On the automatic defense of meaning. Personality and Social Psychology Bulletin, 36, 1372-1384. http://dx.doi.org/10.11770146167210383043

Vroom, V. H. (1982). Work and motivation. Malabar, FL: Krieger.

Webster, D. M., \& Kruglanski, A. W. (1994). Individual differences in need for cognitive closure. Journal of Personality and Social Psychology, 67, 1049-1062. http://dx.doi.org/10.1037/0022-3514.67.6.1049

\section{Copyrights}

Copyright for this article is retained by the author(s), with first publication rights granted to the journal.

This is an open-access article distributed under the terms and conditions of the Creative Commons Attribution license (http://creativecommons.org/licenses/by/3.0/). 